\title{
Nancy Wu Hugues Libergier and his Instruments
}

Nancy Wu examines the architects' instruments carved next to the effigy of Hugues Libergier, the thirteenth century designer of the Abbey of Saint-Nicaise in Reims, sheddinglight on tools of the trade, uses of geometry in architectural design, proportional relationships and the stature of medieval men along the way.

One of the most frequently illustrated images of a medieval architect is the tomb slab of Hugues Libergier (Figure 1), who in 1231 began the construction of the Abbey of Saint-Nicaise in Reims. ${ }^{1}$ Hugues (d. 1263) has been immortalized by this famous effigy which, originally located at Saint-Nicaise, was moved to the Cathedral of Reims in 1800 after the destruction of the rémois abbey. ${ }^{2}$ Since 1887 it has remained at its present location, mounted on the interior wall just to the west of the north transept doors. ${ }^{3}$ As can be expected from the effigy of an architect, it is accompanied by several instruments of his profession: a square, a compass, and a measuring rod.

While these instruments are frequently found in conjunction with the representation of architects, whether on tomb slabs, sculpture, in construction scenes on manuscript pages or stained glass panels ${ }^{4}$, it is the square to the right of Hugues that has received the most attention from scholars in search of the secrets of medieval construction (Figure 2). ${ }^{5}$

Scholars who have studied the tomb slab of Hugues Libergier have taken great pains to describe measure and, indeed, to trace the represented instruments. Yet, curiously, few have considered it worthwhile to give equal attention to the miniature building - presumably a model of Saint-Nicaise - cradled in Hugues's right arm. The different treatment given to the instruments and the building, it seems, is dictated by the scale of the objects: the instruments are tantalizingly close to life-size, while the building is unmistakably symbolic. This fact is surely the explanation for the present tendency by some scholars to consider the instruments to be literal representations of thirteenth-century tools. The problems attending such an interpretation are the concern of this paper. I will review the various strategies and applications adopted by scholars in this regard during the last few decades, and examine the dimensions of these engraved images in relation to those of actual architectural elements. The result of these considerations suggests that the engraved images might not have been intended as a literal "tothe-scale" documentation of medieval tools. Rather, they are iconic attributes proclaiming the 


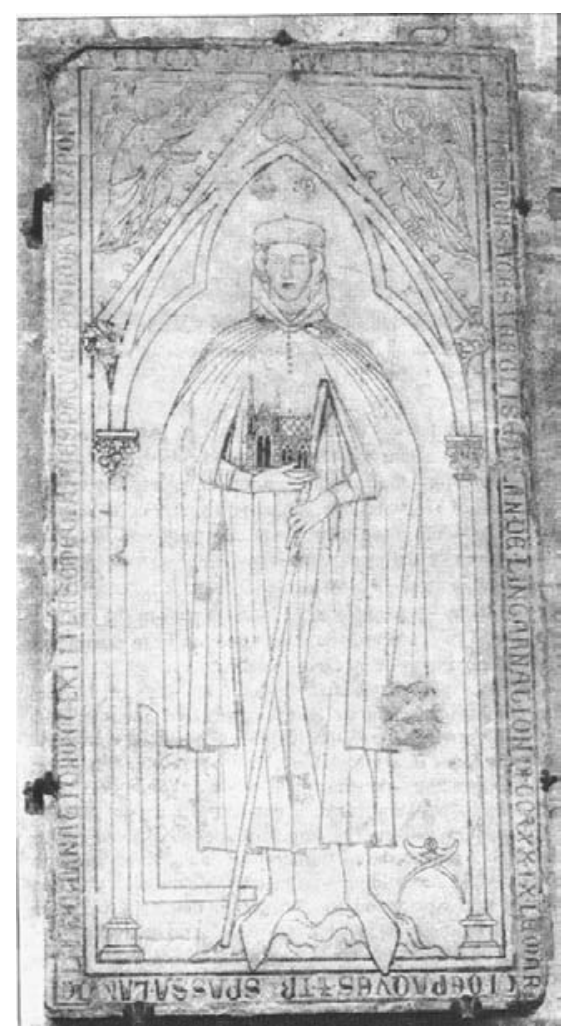

Figure 1.

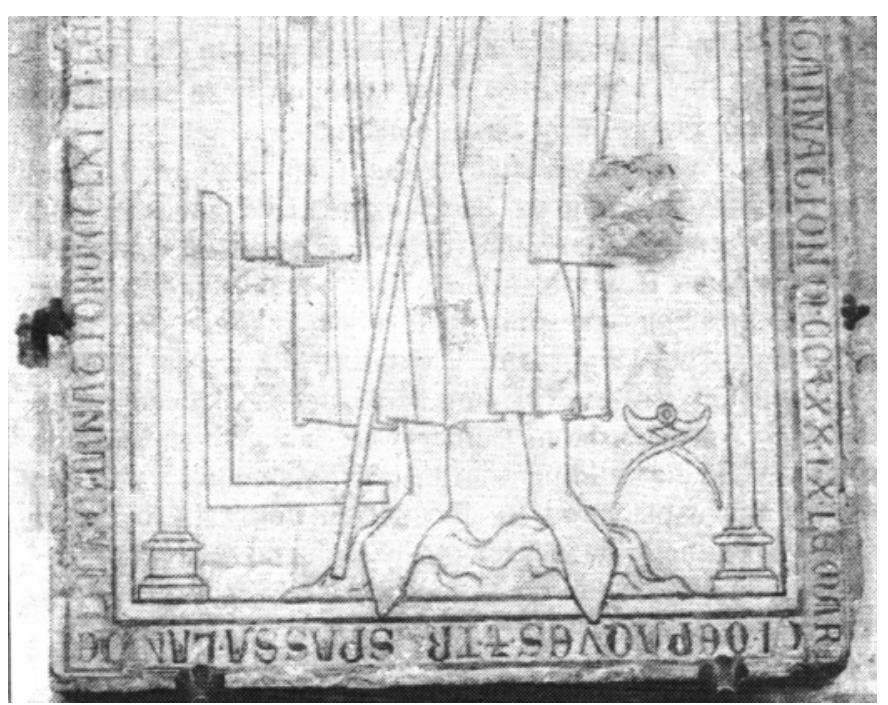

Figure 2.

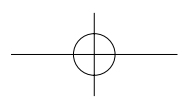


profession of the person for whom the tomb was created.

The square can be documented as far back as the ancient world, with a small number of surviving examples. ${ }^{6}$ The various functions it served in the medieval building trade can be glimpsed from representations demonstrating practical methods or depicting construction scenes. The square, for example, appears at least four times in the drawings of Villard de Honnecourt, which show it used for the cutting of stone blocks and as an aid to obtain the diameter of a column. ${ }^{7}$ The square's practical usage demonstrated by Villard is affirmed in numerous construction scenes in which it is employed for checking the angle of stone blocks or for creating templates. ${ }^{8}$ These visual depictions strongly indicate that the prevalent use of the square was for the workmen to trace angles or outlines in preparation for stone cutting.

The construction of the square was of two major types (each with its variants): the straightarm square, or the square with tapering arms. The length of the arms varied, as did the angles the arms enclosed. While it is easy to ascertain the function of straight-arm squares for anglechecking, the function(s) of squares with tapering arms is much more uncertain and has become the subject of intense debate. A diagram produced by Marie-Therese Sarrade, for example, shows a reconstructed square traced from a twelfth-century tomb slab at Ligne-des-Bois in Charente (Figure 3). ${ }^{9}$ According to the author, both the inner and outer edges of the square enclose ninety-degree angles; however the outer and inner edges are not parallel to each other but at variance of $4^{\circ}-45^{\prime}$, so that the arms taper. Sarrade alleges that the tapering arms of the instrument allow the construction of two kinds of rectangles: one whose long and short sides have a ratio of $1: \sqrt{2}$, and the other, a ratio of $1: 1^{1 / 2}$. Her method of arriving at the larger, $1 \frac{1}{1} 2$ rectangle is by lining up the inner side of the square's short arm with the long side of the smaller, $\sqrt{2}$ rectangle so that the outer edge of the square's long arm touches the end point (Figure 3). By following the slanted outer edge of the long arm to the point of its intersection with the parallel side of the $\sqrt{2}$ rectangle, she claims to derive dimensions of the $1^{1 / 1} 2$ rectangle. Though this may be mathematically correct, we must take on faith that the original of Sarrade's reconstruction indeed was fashioned for the claimed purpose.

The popularity of the $\sqrt{2}$ is well-known, and is found not only in the design of many medieval structures such as Reims, Amiens, Saint-Quentin, and Saint-Urbain in Troyes, ${ }^{10}$ but recorded in treatises on geometry and algebra as well. ${ }^{11}$ We are aware that this ancient ratio, geometrically expressed by the ratio of the side of a square to its diagonal, belonged to a set of approximations known since late antiquity. ${ }^{12}$ It would seem natural for medieval masons to design "customized" squares that would facilitate stone-cutting at the required angles and ratios. However, the reconstruction suggested by Sarrade does not provide a faster, more convenient way for the masons to obtain the ratios. This is because, according to her demonstration, one of the two rectangles must be constructed first, followed by the juggling of the instrument to locate the other rectangle. Since the construction of both the $1^{1 / 2}$ and $\sqrt{2}$ rectangles is quite easy, the supposition that the slanting arms of the square would help expedite the process is open to question.

Already in 1961 a similar, but not identical, purpose for the instrument was proposed by B. G. Morgan. ${ }^{13}$ Having studied the dimensions of almost thirty buildings constructed from the thirteenth through the sixteenth centuries in England, Morgan noted that a high percentage of those constructed after the thirteenth century for or associated with royalty have bay widths based on a module of $23^{1 / 2}$ feet. Believing that the dimensions were arrived at geometrically, he 
suggests that a number of right-angled triangles may be constructed using two of the bay-width dimensions for the length of the sides enclosing the right angle. ${ }^{14}$ Two types of triangles are of particular importance to his thesis: the "general triangle" which encloses the three angles $90^{\circ}$, $60^{\circ}, 30^{\circ}$, and the "canonical triangle" (for its royal association), which encloses the three angles of $90^{\circ}, 58^{\circ} 17^{\prime}$ and $31^{\circ} 43^{\prime} .{ }^{15}$ The angles enclosed by the so-called "canonical triangle" are in fact almost identical to a "Golden Number triangle". ${ }^{16}$

In order to construct these triangular units for the buildings, Morgan alleges that squares enclosing the required angles would have been needed. He first proposes that the ratio of any square's two arms would have been a universal $1: \sqrt{3}{ }^{17}$, a ratio he happily finds in the square on the tomb slab of Hugues Libergier. ${ }^{18}$ Furthermore, Morgan calculates that the straight outer edges of Hugues's square enclose the three angles $90^{\circ}, 60^{\circ}, 30^{\circ}$ of the so-called "general triangle", while their tapering inner edges enclose the three angles of $90^{\circ}, 58^{\circ} 29^{\prime} 50^{\prime \prime}$, and $31^{\circ} 30^{\prime} 10^{\prime \prime}$, which are almost identical to the angles of his so-called "canonical triangle". Because Morgan is able to relate the angles enclosed by Hugues's square with angles he finds relevant in the design of buildings, he asserts that this square was "a full-scale representation of a 13th-century instrument" traced from an actual mason's square, one that was possibly Hugues Libergier's own instrument. ${ }^{19}$ With statements like these, the function of the square is no longer limited to the task of cutting stones. The square, we are told, is a sophisticated instrument employed by the master mason for designing buildings on a monumental scale.

Another attempt to associate the instrument with the design of actual buildings was made

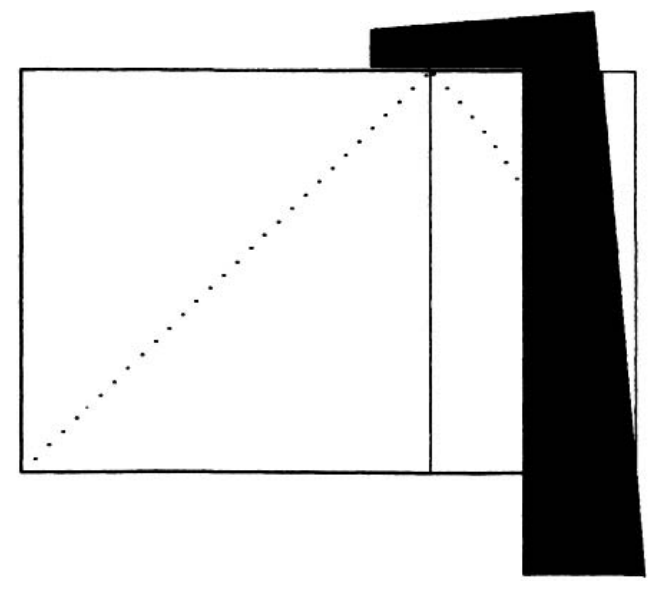

Figure 3.

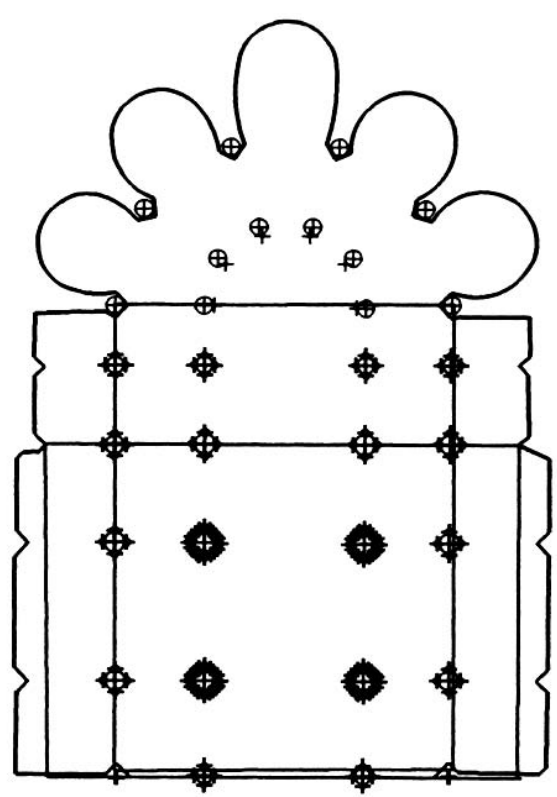

Figure 4. 
in 1982 by Legendre and Veillerot. In their analysis of the ground plan of Reims Cathedral the authors propose to have identified two proportional systems imbedded in the design: a triangle consisting of $90^{\circ}, 36^{\circ}$ and $54^{\circ}$ (the "decagonal triangle", a segment of an evenly divided decagon measuring exactly $36^{\circ}$ ), and a triangle consisting of the Golden Ratio. ${ }^{20}$ Of medieval squares with slanting arms studied by the authors, only those depicted in the album of Villard de Honnecourt could produce both triangles simultaneously. ${ }^{21}$ Legendre and Veillerot proceed to demonstrate the design sequence of Reims Cathedral in twenty-two steps, beginning with the overall envelope (by means of the decagonal triangle) encompassing the entire area of the cathedral, followed by the placement of the west façade (using the Golden Ratio triangle), the division of nave bay units (using both triangles), the transept (both triangles), the choir straight bays (the Golden Ratio triangle) and finally the five-bay east end (the decagonal triangle). ${ }^{22}$ The employment of either triangle in the design of the ground plan does not seem to conform to a particular order, nor have the authors justified the west-east progression of their sequence which, albeit a hypothetical reconstruction, would have been highly unusual in the case of Reims. ${ }^{23}$ The suggestion that $36^{\circ}$ angles are imbedded in the Reims design, particularly in the east end, is quite understandable since any building with a five-sided east end could easily be interpreted to have been conceived as half of a decagon with five $36^{\circ}$ wedges.

It is of course tempting to want to relate squares represented in a group of early thirteenthcentury drawings to a major contemporary building, especially if the artist who executed the drawings was known to have visited the edifice. However, such hypothetical connections must be treated with extreme caution, particularly if the dimensions of the building do not support the theory. ${ }^{24}$ For example, Robert Branner already pointed out that the hemicycle of Reims encompasses an area larger than $184^{\circ} .{ }^{25} \mathrm{In}$ fact, fresh measurements confirm that four of the five hemicycle bays are larger than $36^{\circ} 26$ By superimposing a theoretical decagon on a schematic ground plan, the complexity of the design is masked. its intricacies obscured. My own analysis of the design suggests that the genesis of the Reims hemicycle derived from one circle, not a decagon, since four of the six hemicycle piers stand on the circumference of one theoretical circle. However, due to factors such as possibly the desire to create a rhythmical progression towards the east by flanking the wide axial bay with narrower outer bays and/or errors which may have occurred during the staking process, the not-so-perfect five-sided hemicycle came into being. The suggestion that the area encompassing the choir straight bays and the transept is produced by means of the two triangles respectively is also problematic. Again I refer to the dimensions of the building itself which strongly suggest that it was most probably conceived by means of two overlapping $\sqrt{ } 2$ rectangles, a much simpler procedure for such an immense space (Figure 4).

This review of scholarship, though in no way comprehensive, demonstrates how much scrutiny has been given to the square of Hugues Libergier. As to the larger question of relationships between represented instruments and actual buildings, whether geometrical or metrological, I myself have attempted the same, wanting to relate the dimension of the measuring rod on this very tomb slab to the measurements of Reims Cathedral. I have observed, for example, that the overall length of the rod, which measures approximately 157 centimeters, is almost identical to the diameter of the six hemicycle piers of 157.5 centimeters. This dimension can be interpreted as a five-foot unit, with each foot measuring 31.5 centimeters 
which approximates a foot unit of 31.7 centimeters recorded to have existed in the Departement de la Marne in pre-metric France. ${ }^{27} \mathrm{I}$ attempted to use this convenient foot to explain the bay width (north-south) of the south aisles in the choir straight bays which is otherwise incompatible with the width of the central aisle. The 31.5 centimeter foot allows me to argue that the bay width was conceived as a 25 -foot module, a module that is exactly half of the 50foot central aisle (which was laid out with a shorter foot, probably unintentionally). The potential danger of my string of hypotheses is that they depend totally on the exact dimension of the rod. Because even a slight discrepancy of two centimeters can instantly invalidate such an interpretation, the measuring rod must be exactly 157 centimeters. Theoretical reconstructions proposed by other scholars so far examined depend just as much on the exact dimensions of the instruments.

The potential consequences of a literal, metrological reading of such engraved images compel us to reexamine any assumption that we are dealing with full-scale representations of actual tools, rather than emblematic references. If the assumption is made that the dimensions of the instruments are represented to scale, what about the image of Hugues himself? Might we be looking at the exact height of the architect?

Here the numbers become quite intriguing. The overall dimension of the effigy of Hugues, as it turns out, measures 2.1 meters from the tip of his hat to his toes. ${ }^{28}$ Even if the 23 centimeter distance from ankle to toe were subtracted, he still would have been an impressive man of 1.87 meters (or slightly over 6 feet 1 inch). This seems unusual for a thirteenth-century person, as male adults over 6 feet in today's general population are still regarded as tall. Of course it is possible that Hugues was tall, but alas this could never be confirmed. However, a quick look at extant medieval effigies indicates that their height tends to be exaggerated.

In a survey of more than 200 thirteenth-century English effigies, H. A. Tummers provides the body length of 166 examples. ${ }^{29}$ Among them, forty-two effigies measure more than two meters ( 6 feet 6 inches), twenty-six are between 1.9 (almost 6 feet 3 inches) and 2 meters, and fifteen between 1.8 ( 5 feet 11 inches) and 1.9 meters. In sum, eighty-three effigies are taller than 5 feet 11 inches, which represent exactly half of the effigies listed. However, these numbers are not supported by dimensions of eleventh-and twelfth-century human skeletons recently excavated from a medieval cemetery, the so-called Saint Nicholas Shambles in London. ${ }^{30}$ We learn from the 234 skeletons buried near the parish church that adult men ranged from a little over 5 feet 2 inches to about 6 feet 2 inches, while adult women were anywhere between 4 feet 9 inches and 5 feet 8 inches. ${ }^{31}$ It is important to note that the average height of males is about 5 feet 8 inches, and that of females, 5 feet 2 inches. The average male and female statures extracted from the Saint Nicholas Shambles are quite consistent with measurements obtained from at least fourteen other medieval burial sites in England. The height of male skeletons from the Saxon period through the sixteenth century, from Kent to Durham, ranged between 5 feet 5 inches and 5 feet 10 inches. Female skeletons from these grave sites ranged from 5 feet 1 inch to 5 feet 5 inches. ${ }^{32}$ Clearly the vast majority of medieval English men were shorter than 5 feet 11 inches, or 1.8 meters. On the other hand, the survey by Tummers lists only forty-three effigies ( $26 \%$ of total effigies measured) which measure between 1.6 ( 5 feet $2^{1 / 2}$ inches) and 1.8 meters ( 5 feet 11 inches), the average height of the medieval English population. Moreover, the number of "average-sized" effigies is the same as that of effigies over two meters alone! French examples 
from the same period yield comparable results. The thirteenth-century effigy of Jean d'Alluye at the Cloisters Museum (25.120.210), for example, measures about 6 feet $l$ inch from cranium to heel (Figure 5). The effigy of Margaret of Gloucester in the same collection (53.137), also of the thirteenth century, is longer than 6 feet 4 inches! ${ }^{33}$

Thus, Hugues's effigy most probably does not represent the actual height of the architect. In addition, another look at the measuring rod he holds provides intriguing observations. The rod has often been referred to as a vergette, or marker, which is a rather general term used to describe such a measuring or marking instrument. However, in several descriptions published in the nineteenth century it was also referred to as a toise, which is a more specific, pre-metric term used to describe a measuring unit. ${ }^{34}$ That such terms appeared frequently in early nineteenth-century literature is understandable, as the metric system was not permanently implemented in France until 1837. It is therefore natural that Prosper Tarbé's description of the slab, published in 1844, still used pre-metric terms such as toise, pied, or pouce when providing dimensions. ${ }^{35}$ If we were to take his description of Hugues literally (Il tient de la main gauche une toise, et dans la main droite un petit monument qui represente le projet de la basilique de St.-Nicaise), we must assume that the rod measures exactly six pieds. ${ }^{36}$ However, if the total length of the rod, measuring 1.57 meters, is divided by six (pieds), each pied would measure just over 26 centimeters - an uncommonly short foot unit not documented in medieval literature. ${ }^{37}$ Likewise, it can be argued that my own division of the rod by five (resulting in a foot unit of 31.5 centimeters, which can be applied to a number of dimensions at Reims Cathedral), though very seductive, is equally speculative and unprovable. Since the rod is not a literal representation of a toise, the equivalent of six pieds, the question arises whether the rod is intended to represent an actual toise at all or merely serves as an emblem associated with architects.

In pursuit of an answer, I compared modern readings of the slab's overall dimensions against those given by Tarbé. The height of the slab, according to Tarbé, measures 8 pieds and 8 pouces; while in metric terms it measures approximately 2.78 meters. Dividing the latter by the former, each pied measures 32 centimeters, which is very close to the medieval pied du roi. I was able to confirm Tarbé's systematic use of the quasi-royal foot throughout his writing by checking the width of the slab (1.39 meters) in the same manner (1.39 meters $/ 4$ pieds 4 pouces) to arrive at a foot of 32 centimeters. These simple calculations allow us to

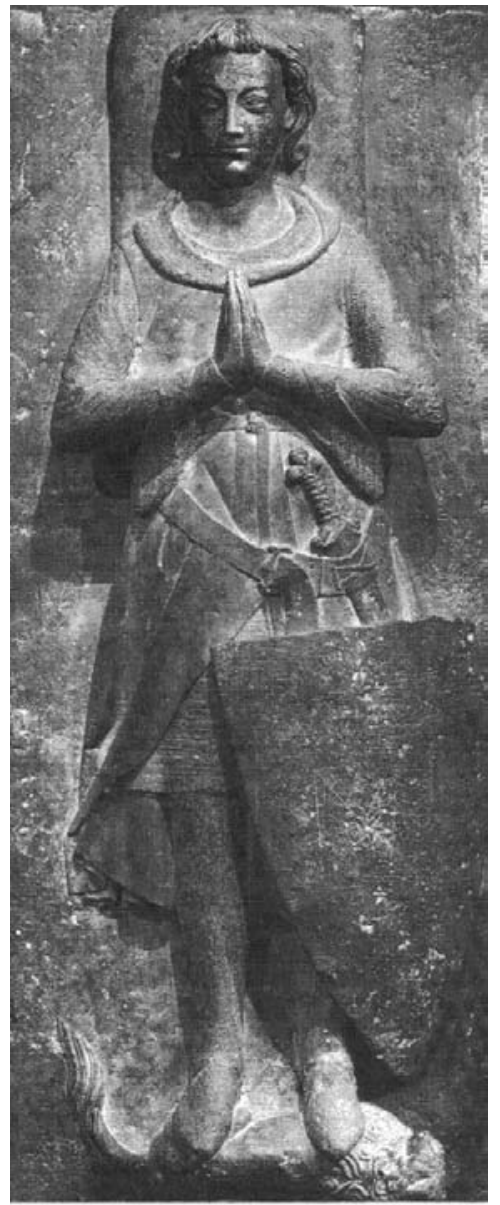

Figure 5 . 
ascertain that the representation of the rod, even though it has been referred to as a toise, bears no relationship to any measuring unit known by that name in pre-metric France. ${ }^{38}$ Tarbé treated the word toise, when describing the rod, as a generic term for a measuring tool and nothing more. If the dimensions of the rod and of Hugues's effigy do not reflect actual sizes, is the engraved square representative of an actual square? If indeed none of these images represent actual dimensions, how do we regard the various dimensions and angles derived so meticulously from these images, and their applications to medieval buildings? ${ }^{39}$

The square's function as a mason's tool and as a design instrument cannot be ignored. And if a square - or any image for that matter - is engraved on a thirteenth-century tomb slab, it ought to be studied, traced, and scrutinized in every way possible. The challenge, though, is to be able to distinguish between representational and emblematic images. Even if a correlation is established between the dimensions of the tools and the building, the assumption that they are causally related must remain hypothetical.

First published in the NNJ online October 2000

\section{Acknowledgment}

This article was first published in Avista Forum (Journal of the Association Villard de Honnecourt for the Interdisciplinary Study of Medieval Technology, Science and Art) 11, no. 2 (Fall 1998 / Winter 1999). It is dedicated to the late Alfred Fraser, who first alerted the author to the issues and the attendant problems associated with Hugues and his instruments.

\section{Notes}

1. M. Bideault and C. Lautier, Saint-Nicaise de Reims, "Chronologie et nouvelles remarques sur 1'architecture", Bulletin monumental 135 (1977), pp. 295-330; C. Givelet, L'eglise et l'abbaye de St.-Nicaise de Reims (Reims, 1897); J. Cossé-Durlin, Cartulaire de Saint-Nicaise de Reims (Paris, 1991).

2. Bideault and Lautier, op. cit., p. 297; D. Kimpel and R. Suckale, Die gotische Architektur in Frankreich, 1130-1270 (Munich, 1985), p. 346.

3. H. Jadart, "Les inscriptions lapidaires de Notre-Dame de Reims", Travaux de l'Academie nationale de Reims 118 (1904-O5), p.17.

4. P. du Colombier, Les Chantiers des cathédrales (Paris, 1973); R. Recht, et al,. Les Bâtisseurs des cathedrales gothiques (Strasbourg, 1989); O. Chapelot, "Quelques reflexions sur les chantiers de construction en France dans les deux clerniers siècles du Moyen Age”, Les Bâtisseurs du Moyen Age, in Dossiers d'Archéologie 219 (Dec.1996-Jan. 1997), pp. 32-39.

5. L. Legendre and J.-M. Veillerot, "L'architecte, l'équerre et la géometrie instrumentale au Moyen Age: analyse du plan de la Cathédrale de Reims", Médiévales I (1982), pp. 48-84; B.G. Morgan, Canonic Design in English Medieval Architecture: the Origins and Nature of Systematic Architectural Design in England, 1215-1515 (Liverpool, 1961); A. Sene, "Un instrument de precision au service des artistes du Moyen Age: l'équerre", Cahiers de civilisation medievale 13 (1970), pp. 349-358; A. Sene, "Quelques instruments des architectes", Actes du congres de la Société des historiens médiévales de l'enseignment supérieur (Besanqon, 1972), pp. 39-58; C. Lalbat, G. Margueritte. and J. Martin, "De la stéréotomie médiévale: la coupe des pieres chez Villard de Honnecourt", Bulletin monumental, 145 (1987), pp. 387-406; L. Shelby, "Medieval Masons' Tools II. Compass and Square", Technology and Culture, 6 (1965), pp. 236-248; J. James, "The Tools of Hues Libergier, Master Mason of the Thirteenth Century”, Architectural Theory Review 2/1 (1997), pp. 142-149. 
6. J. Murdoch, Album of Science, Antiquity and the Middle Ages (New York, 1984); H. Michel, Scientific Instruments in Art and History (New York, 1996); H. W. Dickinson, "A Brief History of Draughtsmen's Instruments", Transactions of the Newcomen Society, 27 (1949-50), pp. 73-84.

7. L. Shelby, "Setting out the Keystones of Pointed Arches: A Note on Medieval 'Baugeometrie', Technology and Culture, 10 (1969), pp. 537-548; Lalbat, Margueritte, and Martin, "De la stéréotomie" (see note 5); R. Branner, "Three Problems from the Villard de Honnecourt Manuscript", Art Bulletin, 39 (1957), pp. 61-66; R. Branner, "Villard de Honnecourt, Archimedes, and Chartres", Journal of the Society of Architectural Historians, 19 (1960), pp. 91-96; H. Hahnloser, "Villard de Honnecourt, kritische Gesamtausgabe des Bauhüttenbuches" ms. fr. 19093 des Pariser Nationalbibliothek (Graz, 1972), especially pp. 361- 368; F. Bucher, Architector. The Lodge Books and Sketchbooks of Medieval Architects, I (New York, 1979); R. Bechmann, Villard de Honnecourt, la pensée tech nique au XIIIe siècle et sa communication, especially chapter Vl, "Construction et stéréotomie", pp. 169-230.

8. The representations of building the Tower of Babel, a popular Old Testament subject, constitute a substantial body of medieval construction scenes. Numerous examples are illustrated in du Colombier and Recht. See note 4.

9. M.-Th. Sarrade, Les connaissances mathématiques des constructeurs du Moyen Age (Paris, 1986); see also Recht, Les Bâtisseurs (as in note 4), p. 236, figs. 2-3; and Bechmann, Villard de Honnecourt (see note 7), pp. 193-194, figure 112-b. The illustration that appears as figure 3 is a composite based on the version published by Recht, Les Battisseurs (as in note 4), p. 236, fig.3.

10. The popularity of $\sqrt{ } 2$ is in no way limited to the continent. For English buildings, see E. Fernie, Romanesque Architecture: Design, Meaning and Metrology (London, 1995) and idem, "Historical Metrology and Architectural History", Art History 1 (1978), pp. 383-399. In Gothic England, consult at least P. Kidson, "A Metrological Investigation", Journal of the Warburg and Courtauld Institutes, 53 (1990), pp. 71-97; and idem, "The Historical Circumstances and the Principles of the Design", in T. Cocke and P. Kidson, Salisbury Cathedral, Perspectives on the Architectural History (London, 1993), pp. 35-91.

11. Recht, Les Bâtisseurs (as in note 4), pp. 238-239; Bechmann, Villard de Honnecourt, p. 193.

12. Kidson, Salisbury Cathedral (as in note 10), pp. 92-93.

13. B.G. Morgan, Canonic Design (as in note 5), particularly chapter IV, "The Canonic Triangle", pp. 45-54, and chapter V, “The Master Mason's Square”, pp. 55-69.

14. Ibid., p. 48.

15. Ibid., p. 55.

16. The three angles of an exact Golden number triangle are: $90^{\circ}, 31^{\circ} 43^{\prime}$, and $58^{\circ} 16^{\prime}$. Morgan, Canonic Design (as in note 5), p. 52.

17. "The thesis that the several bay-width dimensions of 'royal' work are geometrically related stems from an examination of the form of the mediaeval mason's square, and, in particular, from the observation that the arms of the square appear to have a length relationship of $1: \sqrt{3}$.” Morgan, Canonic Design (as in note 5), p. 55.

18. Ibid., pp. 55-61.

19. In fact, he remarked amusingly that "the carver of the tomb could hardly have anticipated that this ancillary symbol would become the subject of critical interest seven hundred years after his death." Morgan, Canonic Design (as in note 5), p. 61. J. James's recent study echoes Morgan's view in believing that the square, along with the compass and measuring rod, were "probably precisely those used by Hugues himself." James actually measured all three instruments on the slab from both their inner and outer edges of the lead-filled outlines, concluding that only "the outer edge of the lead coincided with the original outline of the tools." James, "The Tools of Hues Libergier" (as in note 5), pp. 142-143.

20. Legendre and Veillerot, "L’architecte, l'équerre et la géometrie au Moyen Age" (as in note 5), p. 67.

21. Ibid., pp. 68-71. When discussing the Libergier square in their survey, the authors adopted Morgan's analysis wholeheartedly. Cf. pp. 64-65.

22. Ibid., pp. 73-76.

23. Though suggestions have been made that the nave of Reims might have preceded the east end, the majority of scholars agree that the east end must have been begun before the nave and the west façade. This has been confirmed by the recent excavation of the cathedral's foundation in which fragments from earlier structures thrown into the foundation are found primarily east of the nave proper.

24. The study of Legendre and Veillerot includes diagrams that are perfect examples of over-reading into a ground plan design, tiling it with a maze of lines that do not necessarily indicate any actual members or spatial units of 
the building. See also G. Lesser, Gothic Cathedrals and Sacred Geometry (London, 1957), plate XLIX; M. and D. Jay, Le symbolisme des nombres à la cathédrale de Reims, le nombre d'or dans le plan de la cathédrale (Reims, 1961): especially pp. 61-64.

25. R. Branner, "Jean d'Orbais and the Cathedral of Reims", Art Bulletin 43 (1961), pp. 131-133. Another famous example of such an hémicycle outrepassé is at Bourges.

26. The angles of the five radiating bays are (from north to south): $36.215^{\circ}, 37.770^{\circ}, 38.698^{\circ}, 37.628^{\circ}$, and $38.090^{\circ}$. For an analysis of the Reims hemicycle, see N. Wu, Uncovering the Hidden Codes: The Geometry of the East End of Reims Cathedral, Ph.D. dissertation (Columbia University, 1996), pp. 53-71.

27. J. Poterlet, Tables de comparaison entre les mesures anciennes usitées dans le Departement de la Marne (Chaalons, 1803), p. 3.

28. Some of the measurements provided here were obtained by Marie-Therise Zenner, to whom I am grateful.

29. H. A. Tummers, Early Secular Effigies in England: The 13th Century (Leiden, 1980), pp. 135-147.

30. W. White, Skeletal Remains from the Cemetery of St. Nicholas Shambles, City of London (London, 1988).

31. Of all the skeletons complete enough for calculating body height, only five are over 180 centimeters (or just under 6 feet). Only one is over 6 feet.

32. White, Skeletal Remains (as in note 30), p. 31.

33. Information on the body height of medieval French men and women is scarce, and so are precise dimensions of effigies.

34. I. Taylor, Voyages pittoresques et romantiques dans l'ancienne France (Paris, 1857), p. 132; P. Tarbé, Reims: Essais historiques sur ses rues et ses monuments (Reims, 1844), pp.274-275.

35. 1 toise $=6$ pieds $=72$ pouces.

36. Tarbé, Voyages pittoresques et romantiques (as in note 34), p. 275.

37. The shortest foot I have come across is the so-called pied d'eveche of $27.07 \mathrm{~cm}$. used in Metz and Rouen, known as the pied de 10 pouces de Paris. Cf. H. Doursther, Dictionnaire universel des poids et mesures anciens et modernes (Amsterdam, 1865), pp. 402-416.

38. A. E. Berriman, Historical Metrology: A New Analysis of the Archaeological and the Historical Evidence Relating to Weights and Measures (London, 1953), pp. 136-139

30. See Shelby, "Masons' Tools" (as in note 5), pp. 247-248.

\section{The Author}

Nancy Wu received her PhD in Art History from Columbia University in 1996. She is currently Head of Education at The Cloisters, the medieval branch of The Metropolitan Museum of Art. She has presented numerous papers at The International Congress of Medieval Studies at Kalamazoo, Michigan, the International Medieval Congress at Leeds, UK, and at the annual meetings of the Society of Architectural Historians. Presently, she is editing - as well as contributing an article to - Ad Quadratum, a volume dedicated to the art of practical geometry and medieval architecture, sponsored by Avista and to be published by Ashgate Publishing. She also serves on the Programming Committee of the International Medieval Congress at Leeds, UK, and is responsible for programming all art history and architectural sessions of the conference. 